\title{
EFFECTIVE LEARNing OF LANGUAGE FUNCTIONS IN M.E.
}

\section{ZANIC MIKULICIC, J.}

Abstract: To be safe at sea it is important to be able to communicate effectively in English. Maritime English (M.E.) lecturer should teach the students the vocabulary and grammar required for efficient carrying out specific tasks in communication off and on shore. The theme of this paper is functional aspect of the English language used as means of interpersonal intercultural communication. The paper notes that the process of consolidation of memorizing information and definitions is associated with previously learned words which then seek association with remembered concepts and learned grammar. The aim is to test, through the method of Discourse Completion Test, how successfully students use English language on board and off shore, as well as specific commands due to the rules of IMO. The results of this research showed that more systematic approach to acquire vocabulary and more difficult language structures is needed. It can be concluded that in the written communication students without adopted terminology hardly stay in the topic of conversation and during their professional communication more concise and clear sentences should be used.

Key words: Maritime English, interpersonal and cross cultural communication, functional aspect of language, systematic approach
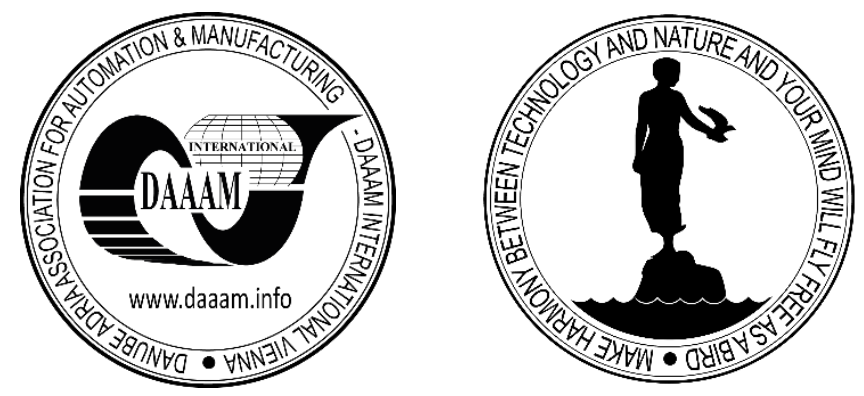

Authors' data: Zanic Mikulicic, J[elena $]^{*}, *$ University of Maritime Studies, Rudera Boskovica 37, 21000, Split, Croatia, jzanic@pfst.hr

This Publication has to be referred as: Zanic Mikulicic, J[elena] (2016). Effective Learning of Language Functions in M.E., Chapter 15 in DAAAM International Scientific Book 2016, pp.163-174, B. Katalinic (Ed.), Published by DAAAM International, ISBN 978-3-902734-09-9, ISSN 1726-9687, Vienna, Austria

DOI: 10.2507/daaam.scibook.2016.15 


\section{Introduction}

This paper explains how essential it is for students of Maritime studies to know the basic functions of English as global language. Also, the set of standards for Maritime English in Navy education and training programmes for students, cadets and officers of various types and ranks in other European maritime tradition will be considered. These standards are based on transfer of innovation from existing English language standards and Maritime English model courses such as International Maritime Organisation (IMO). Research made on this topic identified that there was a great need to promote a high level of Maritime English language skills for students and later on merchant navy officers. While learning language, students have opportunities to perform some linguistic functions like asking permission, asking for information and making a request. However, these are not the only uses of English in daily life. Acquiring language functions of Maritime English must go through several phases. First of all it is important to understand and learn grammar and appropriate vocabulary and thus Maritime English splits into learning phases. First one concerns the standards of Maritime English competency for Deck Officers, second one relates to competency level for Maritime Engineering Officers. The paper wants to illustrate that in order to use English effectively on the board, on and offshore or for social communication, students need to practice performing other functions in English. Some commonly used functions are asking for clarifications, apologizing etc. Students going on board must speak a proper Maritime English if they want to establish a good communication between crew members of different nationalities. For the purpose of this paper, students were given Discourse Completion Test through five questions. The results of it gave feedback how it developed their skills in performing language functions. The scope of the paper is also to discover how efficiently students communicate in English language on board and off shore according to the IMO standards. They are also advised how to use SMCP in order to improve their language skills.

\section{Functions of Maritime English}

Maritime English is specific kind of English language, the global language used at sea. It is lingua franca or common language used for clear communication between ship and shore and crew members. It has acquired its own vocabulary, grammar and phonology, semiotic systems, specific means of communication, language functions and patterns. Knowledge and skills of Maritime English can ensure the effectiveness of communication between English speaking seafarers and non-English speaking seafarers. Good communication in Maritime English is essential for creation and maintenance of effective working environment and safety of the crew and generally safety at sea and ports. To some extent, guarantee of safety at sea relies on seafarers' communication in Maritime English. Proper command of Maritime English is not only 
for the essentials of seafarers but also for the appropriate operation of ship (Horck, 2005). Although IMO has officially adopted Maritime English as the language of maritime industry, there is also necessity for ensuring seafarers to gain Maritime English communication skills in the current globalizing world shipping market. Most of maritime universities are aware that mastering communication skills is one of the important components which ensure the safety at sea. In order to cultivate the highquality seafarers, Maritime English teachers should focus on teaching the particular terminology and communication skills that include listening, speaking, reading and writing. Language functions on the other hand refer to the purposes in which person uses language to communicate (Jones, 1981).

Language is used for a variety of normal and informal purposes and specific grammatical structures and vocabulary are often used with each language function. According to Searle (2003) some examples of language functions include:

- Compare and contrast

- Persuasion

- Asking questions

- Expressing likes and dislikes

- Cause and effect

- Summarizing

- Sequencing

- Predicting

- Agreeing/disagreeing

- Greeting people/introductions

When uttering words the speaker keeps in mind psychological and functional role of the language.

As can be seen in the Figure 1 (Searle, 2003), the language background (general English language) is so called learned material (grammar, lexis and language functions) that helps students connect the content in their head with the appropriate formality and to produce a certain sentence in oral or written form. 


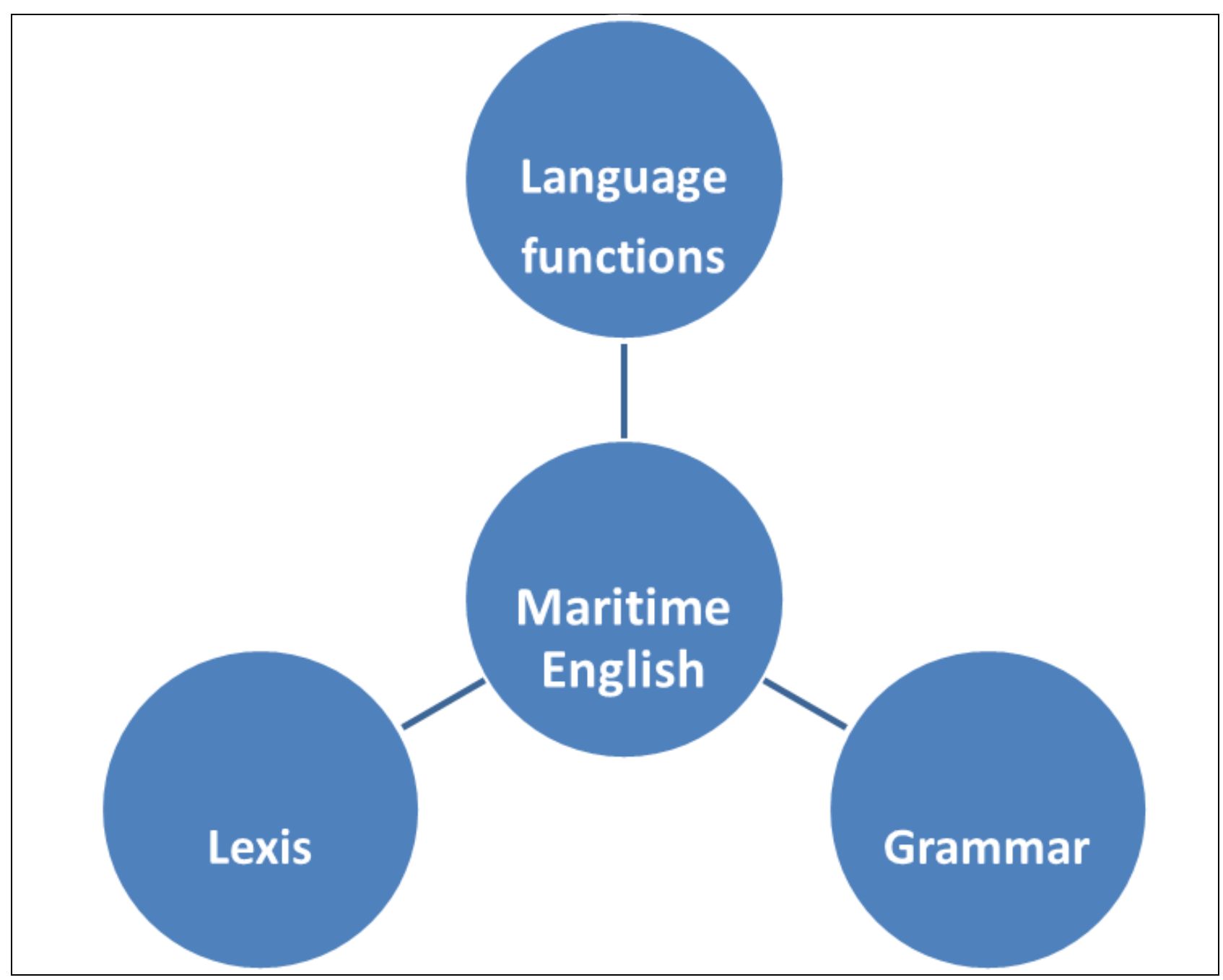

Fig.1. Language functions and Maritime English

According to Kittredge \& Lehrberger (1982) the definition of a sublanguage could identify a very large number of linguistic subsets as sublanguages. Sublanguages or languages of restricted domain are most frequently observed in technical and scientific communications. As a whole, Kittredge said the following: "Maritime English is composed of several contrasting subsystems/sublanguages: (1) general English, (2) general Maritime English, (3) Maritime English for navigation, (4) Maritime English for marine engineering, (5) Maritime English for ship's documentation and correspondence, (6) Maritime English for radio communication, (7) SMCP- standard marine communication phrases, (8) Maritime English for IMO conventions, regulations, manuals, etc." (Kittredge \& Lehrberger, 1982).

\section{Previous Research on this Topic}

Previous research on this topic reveal difficulties in Maritime English teaching, with focus on how to improve four communicative skills in Maritime English teaching. 
Maritime English lecturers play an essential part in realizing the goal of Maritime English teaching. The quality of teaching decides whether the students will become competent seafarers to meet requirements of IMO Conventions and whether they will be communicating freely in the everyday communication.

The contents of standards are based on active learning and on maritime terminology and usage with less emphasis on grammar. As Ziarati (2006) suggests, all standards for Officer and Senior Officer Levels have different weights on different skills and different proficiency requirements at different ranks and duties. For example, a Chief Engineer should be competent on comprehension of reading and writing but a more moderate level of speaking may be tolerated. His research also showed that good communication in Maritime English is essential for creation and maintenance of effective working environments and safety of the crew, and generally safety at sea and ports. Maritime Safety Administration (MSA) did specific testing on Maritime English acquiring. This evaluation revealed some unsatisfactory results. Some students could not use properly language functions or express himself/herself clearly, whether in Maritime English or everyday English. This proves that one can define maritime language through narrow and broad sense. The former includes all language patterns necessary to make strictly professional communication on the board and the latter is important to have normal, everyday communication with the rest of the crew. Interesting is memorizing the technical terms relating to cargo handling gear, for e.g. the phrase standing guy or beam. If students do not have enough knowledge of the vessel structure and its equipment, the confusing homonyms will make them understand it in mistaken way. The beam, meaning in Maritime English breadth or width of the vessel, is usually confused with the sunbeam. Often, when listening to materials, students do not pay attention to the stress, rhythm and intonation of the sentence and soon the meaning of it is gone. There is an example of such communication where the students had to use words such as accompany, sample oil, tank, fetch (Horck, 2005).

Student A: I will take an oil sample from your oil tank. Could you send a crew to accompany me?

Student B: Sure, I will accompany you. If possible, I will fetch samples for you. In this way, one got the impression that they are familiar with the expressions and they understand the meaning of each word but what they missed here is actually the function of language and the sentence as a whole. 


\section{The Study and the Aim}

Through the Study in this paper the difficulties in the process of teaching and learning Maritime English are shown. The research was done on the sample of 58 students of third year who were given a questionnaire i.e. Discourse Completion Test about language patterns and functions. In this test they had to show their language knowledge on the semantical, grammatical and functional level. The aim of this research was to find answers on the following questions; how efficiently do students communicate in English language on board and off shore and do they give concise and clear commands where necessary, according to the IMO standards i.e. did they acquire specific maritime terminology. This is going to reveal major problems relating to competency in Maritime English for the well-being of seafarers, teachers and those working in the shipping and maritime industries (onshore) and including ports (off shore). The problem is addressed at its very roots, that is, helping to improve the language competency of students and those wishing to go abroad. The students were given five described situations in which they had to imagine themselves and try to give their answers. They had to pay attention to the grammar, sequence of words, meaning of the sentence and language functions in general. First, fourth and fifth question test how efficiently students communicate in everyday English language (especially first question) in terms of grammar, speech acts and other language functions which they use spontaneously when talking or writing. Second and third question deal more with Maritime English language in terms of terminology prescribed by IMO and test efficacy of short and simple commands that have to be exchanged between Pilot and Master or Chief Officer also according to some prescribed rules. It is well known that SMCP (standard marine communication phrases) is a comprehensive, standardized, precise, simple and unambiguous language, created to avoid confusion and error (SMCP Resolution, 2001). The students that are learning Maritime English language must adopt English language in a way that they are able to give general information, to speak about loading and discharging cargo when coming to the port and to know terms important for safety and security of the vessel on and off shore. These three levels of Maritime English language were described through the Discourse Completion Test and students were expected to answer them efficiently. From the linguistic point of view SMCP (developed on the principle of conventionalism or agreement) represents a huge scope of terms and phrases denoting objects, notions, actions and procedures.

Five described situations in the Discourse Completion Test are given below;

- You applied for a job in the oil supply company and you are invited to an interview to introduce yourself shortly. Stress is on your qualifications and question why you 
want to get this job. Please give short description of your school background and work experience.

- Your vessel is approaching another one. You as a Master need to communicate with the Master of that vessel and get information on course changes, lowering speed because of the possible collision! In communication with another vessel please use concise Maritime English terminology according to IMO.

- Vessel is approaching the port and you, as a Master or 1st officer, are calling Pilot/Port Authority. You need to get information when and where to anchor in order to discharge your cargo. Through the VHF exchange give general information on your vessel, cargo, last port and ETA. Try to do it in the dialogue form!

- You are not satisfied with the quality of food served in the gallery which is often cold and tasteless. Please express your dislikes to the catering department and its masterchef.

- You got ill on the vessel and need urgent medical care. You have terrible itching and symptoms are red spots all over the body and fever. Ask medical expert politely for advice and further behaviour.

\section{Presentation and Application of Findings}

The results of an initial research on the effective use of Maritime English with the students of third year will be presented. The mentioned presentation of the results is given in relation to each language function of the Discourse Completion Test from the $1^{\text {st }}$ to $5^{\text {th }}$ question.

You applied for a job in the oil supply company and you are invited to an interview to introduce yourself shortly. Stress is on your qualifications and question why you want to get this job. Please give short description of your school background and work experience.

When applying for a job and coming to an interview the seafarer has to be able to introduce himself, to say something about previous occupation and to speak fluently. He should know how to describe himself in correct English language by using as many details as necessary to stress his qualifications in order to get the job. He has to be polite, communicative and avoid short answers like "yes or no". According to the results of this test, $32 \%$ of the students tested started conversation with the sentence: "I'm classified for this job and I should get it." Then they gave information on their education, university, department and their interest in getting this very job. This shows the lack of language patterns and useful terms for starting a conversation which is not near to raise the employer's interest in this person. But still, the reader gets the impression of very high self confidence in getting the job although it is written in impolite way ( should get the job). On the other hand, more than $50 \%$ of the students in this question did not use grammar properly and made mistakes like missing to double consonant in the word classified. $9 \%$ of them did not adopt the word want and confuse 
it with the negative future form won't. Interesting was the answer of $1 \%$ of them who denoted that they are not nervous persons, do not yell, and know how to solve any problem.

Your vessel is approaching another one. You as a Master need to communicate with the Master of that vessel and get information on course changes, lowering speed because of the possible collision! In communication with another vessel please use concise Maritime English terminology according to IMO.

Each country that is a member of the International Maritime Organization (IMO) designates an "Administration" or federal authority for implementing the provisions of the COLREG convention. It sets out the "rules of the road" or navigation rules which must be followed by ships and other vessels at sea to prevent collisions between two or more vessels (Ford, 2009). When answering this question, $42 \%$ of students did not pay attention to the specific rules that they learnt in their courses, considering safety and security on the sea. Here, they had shown the lack of usage of the maritime terminology although the sentence construction was correctly used by $68 \%$ of them. Three students left out this question completely and two of them answered I don't know what to do in this situation. This gave an impression that $2 \%$ of students missed the lesson about the security and safety on the sea and would not be able to handle the given situation. $58 \%$ of students would react in appropriate way; they would communicate with the other vessel and suggest to lower the speed and alter the course. These two expressions are parts of the second COLREG (collision regulations) and this percentage of students adopted important terms and combined it properly in the sentence. Interesting is the fact that all students showed uncertainty when they had to use appropriate modal verb in communication with the master of the other vessel. They used the term Please, may you alter your course, which is inappropriate in this situation, especially when communicating with the vessel which is approaching the wrong direction. Appropriate modal verb in this case would be must, and it is the most frequent one used in terms of collision rules. $2 \%$ of students gave the impression of negotiating with the other vessel and wrote If you do not want to lower the speed, tell us, and we will lower it. This kind of communicating is impermissible in this situation when strict rules and their lawfulness must be followed.

Vessel is approaching the port and you, as a Master or 1st officer, are calling Pilot/Port Authority. You need to get information when and where to anchor in order to discharge your cargo. Through the VHF exchange give general information on your vessel, cargo, last port and ETA. Try to do it in the dialogue form!

The aim of ship's officers and crewmembers on board should be to prevent damage or deterioration whilst the cargo is under their care and to deliver it, as far as possible, in as good condition and order as it was when received aboard. The Master and 1st officers of the vessel require a good working knowledge of the various kinds of cargo they are likely to carry: their peculiar characteristics, liability to damage, decay or deterioration. Furthermore, according to Pritchard (1993) Pilot is the person who steers 
ships into and out of berths, signals tugboat captains to berth and unberth ships. He advises ships' masters on harbour rules and customs procedures.

$39 \%$ of students started communication with the Pilot without using any request forms, correct question techniques etc. They started their conversation with the sentence Hello, give me informations where is my anchoring area. Obviously, they forgot to introduce themselves at the very beginning, give the most important data of the vessel and cargo they were carrying and politely ask for advice and further information. Only $9 \%$ of students gave correct information when opening conversation and showed specified language knowledge. More than $54 \%$ of the students used wrong plural form of the word information.

$17 \%$ of the students did not get the point what to write and misled the question. They switched the roles and gave the description of jobs of the Pilot. Although this was not the answer to the question, it was obvious to notice that they do not know what actually the Pilot does. $7 \%$ of students described briefly Pilot's duties by writing typical definition; pilot takes care of import/export documentation to determine cargo contents, or that he classifies goods into different fee or tariff groups, using a tariff coding system. This implies that some students are familiar with the terminology and definition but they lack praxis in written conversation.

You are not satisfied with the quality of food served in the gallery which is often cold and tasteless. Please express your dislikes to the catering department and its masterchef!

Everyday communication in English language is necessity on the vessel. In the case of this question, the functional role of the language is important. One expects here an utterance that will be produced like the topic about which the speaker wants to express an opinion. Language functions, as well as terms determining agree/disagree, or refusing are welcomed (Lewis \& Hill, 1999). Formality also becomes very important in this type of questions. When looking at the written answers, it seemed that everyone answered this question correctly, meaning that the students understood given question and know how to communicate in English in everyday life. Of the total number of students tested, $61 \%$ of them used formal way of opening conversation and started it with I would like to say that I am not satisfied... Probably one can think that they were following the fact that maybe that person in catering department is an older acquaintance. $16 \%$ of students started conversation immediately with their preferences, giving advice and making suggestions like I think that... If I were you... that can be very impolite without introduction. Only $22 \%$ of students tested, could not express their complaint successfully and did not know actually how to use this language function. $1 \%$ of students simply wrote Please do not cook anymore which is very informal, rude and non-accepted form of behaviour.

You got ill on the vessel and need urgent medical care. You have terrible itching and symptoms are red spots all over the body and fever. Ask medical expert politely for advice and further behaviour. 
As in question before, in this one, students also had to show minimum of their everyday communication in English and give answers in simple meaningful sentences. The level of language knowledge for answering this question is High School English level. It is interesting that $85 \%$ of students had headache and high temperature and so the words headache and temperature are two most frequently used words through this questionnaire. $10 \%$ of students have flu and need proper medical care. No one gave detailed description of his state, kind of illness, asked for the therapy, thought about disembark etc. This implies that almost $95 \%$ of students have difficulties with the language function of describing state or asking for advice. They do not know how to describe their state of illness and how to ask for help.

\section{Discussion}

The results showed that Split Maritime Faculty students of third year usually do not know when to use certain language patterns of English language and think of them as unimportant part of language. From the results it can be concluded that grammar does not play an important role when writing Maritime English. Vocabulary is the thing that matters, according to their results. On the other hand, they cannot remember the appropriate word in the specific moment and use the term right side of the vessel instead of starboard side. Probably, the way of thinking that they can be understood also in this way, makes them not to think about the appropriate Maritime English word.

The first, fourth and fifth question understood giving simple answers with using transition words and phrases but this form was omitted by the students. On the other hand, in the first question one expected more formal style when introducing oneself but it also did not happen in $35 \%$ of them. $12 \%$ of them tried to do it in more formal way but then the sentence was inappropriately structured. Students were mostly expected to be polite, communicative and to avoid short answers like "yes or no". The last mentioned speech act seemed to be the most frequently one.

In order to communicate efficiently students ought to know that formality is an important factor for expressing one's opinion. The lack of it was also shown in fourth and fifth question where $28 \%$ of them did not use opening expressions. This showed the lack of knowledge in this field because they had some thinking time to arrange his/her ideas and form an opinion i.e. sentence. Of the total number of students tested $12 \%$ used correctly the formal opening "I would like to say that I have a problem ..."; and most of them rather used informal phrase "I just want to say that I have ..."

The students were expected to show more language competence in the second and third question than in the last three explained above. They know when and where to use clear commands and $37 \%$ of them did it well. It seems that the maritime phrases without complex grammatical structures are easy to learn and their use is very logical. Their correspondence with Pilot or Master in terms of terminology is satisfactory but they lack right spelling of particular words. 
It is obvious that the results of the test gave answers to our research questions. Students showed poor communications in writing in English language considering grammar, speech acts, transition words and spelling. Previous research and IMO model course 3.17 also acknowledged similar mistakes which happened, they believe, because functional patterns of the Croatian speakers are substantially different from those of the native English speaker. On the other hand, 37\% used correctly concise commands according to the rules of IMO which confirmed that they had learned and understood particular maritime terminology.

\section{Conclusion}

In the focus of this paper is the importance of effective communication at sea and ashore by the seafarers. They are obliged to accomplish appropriate knowledge to communicate effectively and efficiently in Maritime English. Through Discourse Completion Test, the students had to show how their knowledge on Maritime English that included phrases in routine situations as well as standard responses for use in emergency situations. The results of the test illustrated that the level of knowledge of English language by students of maritime science is quite poor and must be raised higher. Results proved that some of the students do not know to express themselves in written form, especially in the first question where they had to introduce themselves shortly. It is obvious that they do not differ formal from informal style of writing and do not know how to complain politely about food (fourth question) regardless of whether they knew the person or not. Considering the answer to the second research question, results showed that $63 \%$ of them did not adopt specific maritime terminology and usually do not know how to incorporate it within language functions. Generally speaking, students are not very efficient in using everyday English language and they need to improve their writing skills. According to this conclusion, lecturers should give the students some writing assignments in order to improve their writing ability. Students that are learning Maritime English must practice the vocabulary and grammatical structures associated with language functions in both, oral and written contexts. Every student should play different role during the process of learning and get acquainted with all the aspects of a proper communication performed in Maritime English. In the future, they must adopt language functions in Maritime English in order to understand specific tasks and act properly according to certain situations. They as future seafarers need English in each situation on board, on and off shore. Misunderstanding of language in written or oral form can bring safety and security in question. 


\section{References}

Ford, J.W.W. (2009). A Seaman's Guide to the Rule of the Road, Morgan's Technical Books, ISBN 9780948254581, Gloucestershire

Horck, J. (2005). Getting the Best from Multi-cultural Manning, BIMCO Bulletin, ISBN 978-91-976140-4-7, (100): 4, Denmark

IMO SMCP Resolution A.918 (22), IMO (International Maritime Organization), Nov. 29, 2001

Jones, L. (1981). Functions of English, CUP, ISBN 978-0521238366, Cambridge

Kittredge, R.; Lehrberger, J. (1982). Sublanguage: Studies of Language in Restricted Semantic Domains, De Gruyter, Sager, ISBN 31100824469783110082449 , Berlin

Lewis, M, Hill, J. (1999). Practical Techniques for Language Teaching, England: Language Teaching Publications, Hove

Pritchard, B. (1993). Maritime English I, Školska knjiga, Zagreb

Searle, J. (2003). An Essay in the Philosophy of Language. CUP, ISBN 0521273021, New York

Ziarati, R. (2006). Safety At Sea-Applying Pareto Analysis, Proceedings of World Maritime Technology Conference (WMTC 06), Queen Elizabeth Conference Centre ***http://www.marifuture.org/Reports/DevelopmentPapers/IMO_New_Model_Cour se_Maritime_English.pdf, Accessed on: 2015-02-10

***http://web.mclink.it/MI2701/rivista/2005gg/Fiorito05gg.pdf, Accessed on: 201502-10 